\author{
ТРАНСФОРМАЦИЯ МАТЕРИНСКО-ДОЧЕРНЕГО СЮЖЕТА \\ В СОВРЕМЕННОЙ ЖЕНСКОЙ ПРОЗЕ \\ (НА МАТЕРИАЛЕ РОМАНА Е. ЧИЖОВОЙ «КРОШКИ ЦАХЕС»)
}

\author{
(C) Татьяна Бреева, Юлия Панибратова
}

\title{
TRANSFORMATION OF A MOTHER-DAUGHTER STORYLINE IN MODERN FEMALE PROSE \\ (BASED ON THE NOVEL "LITTLE ZACHESES" BY E. CHIZHOVA)
}

\section{Tatyana Breeva, Youliya Panibratova}

The theory about mother and daughter relationships, which can restore the lost self-identification of a woman, is recognized as traditional for theorists of feminism. It is this type of relationship that can create a connection between the broken man-woman relationships through a child and re-build the true nature of a woman. However, in Elena Chizhova's "Little Zacheses" these relationships build a completely different structure. The "mother-daughter" plot is first turned upside down when the daughter becomes a mediator in her mother's interactions with the world (not vice versa), later it is perceived as something that destroys the truly female being and consciousness, carefully drawn up by the main character of the novel. Any attempts to display maternal care are either rejected or cause bodily harm on the woman. In the novel, a whole complex of oppositions is built up, isolating the woman from the mother's world, and later from men. Due to the woman's ability to multiply, grow deeper into herself, to be "not one", but "two in one", that is, to be a multiplicity, the main character creates her own being, which is a way of seeking her own identity.

Many researchers turn to a "mother-daughter" plot as an unusually productive storyline in modern female prose. This article is an attempt to consider issues, related to the perception of this dichotomy through the prism of the concept stated by Luce Irigaray in her work "This Sex Which Is Not One".

Keywords: feminism, identity, mother-daughter plot, quasi-being, linguistic and spatial opposition, muscularity, femininity, laughter motif, monstrosity, abnormality

Традиционной для теоретиков феминизма признается теория об отношениях матери и дочери, которые могут восстановить утерянную самоидентификацию женщины. Именно такой тип отношений способен также создать связь и между разрушенными отношениями мужчины и женщины, сделав проводником ребенка, вновь выстроить подлинную природу женщины. Однако в романе Елены Чижовой «Крошки Цахес» данные отношения выстраивают совершенно иную структуру. Материнско-дочерний сюжет сначала выступает в перевернутом виде, когда дочь становится посредником во взаимодействии матери с миром (а не наоборот), а затем воспринимается как нечто разрушающее истинно женское сознание и бытие, тщательно выстраиваемое главной героиней романа. Любые попытки проявить материнскую заботу либо отвергаются, либо наносят телесный вред женщине. В романе выстраивается целый комплекс оппозиций, которые отгораживают женщину от мира матери, а потом мужчины. Благодаря способности женщины множиться, разрастаться вглубь себя, быть «не одной», а «два в одном», то есть быть множественностью, главная героиня создает собственное бытие, являющееся способом поиска собственной идентичности.

Многие исследователи обращаются к материнско-дочернему сюжету как необычайно продуктивному для современной женской прозы. В данной статье предпринята попытка рассмотреть вопросы, связанные с восприятием данной дихотомии через призму концепции, заявленной Люси Иригарэ в работе «Пол, который не единичен». 
Ключевые слова: феминизм, идентичность, материнско-дочерний сюжет, квазибытие, языковая и пространственная оппозиции, мускулинность, феминность, мотив хохота, монструозность, аномальность.

Роман «Крошки Цахес» погружает нас в историю взросления главной героини, ученицы ленинградской школы 1960-х - середины 1970-х годов. Появление новой учительницы английского языка (имя которой не называется и дается лишь короткое «Ф.») проверяет на прочность систему ценностей всей школы. Ф. отличается от других учителей: главная героиня (и рассказчик) сразу замечает, что «никто из учителей так поанглийски не говорил» [Чижова, с. 41]. Мать Ф. «родилась в далекой нерусской деревне» [Там же, c. 10], она работала дворником и не говорила порусски, и дочь стала переводчиком между миром и матерью: «мать не могла быть посредницей между дочерью и миром» [Там же, с. 11]. Дихотомия «мать-дочь» оказывается перевернутой. Отвергается утверждение Иригарэ о материнстве, которое традиционно «заполняет разрывы репрессивной женской сексуальности» [Жеребкина С. В., с. 130]. Материнское начало отрицается Ф., а позднее в романе будет восприниматься даже как враждебное, ускоряющее ход времени, с которым она так неистово борется. Так, например, главная героиня, попав в больницу, вынуждена присматривать за грудными детьми, материнство рассматривается как несвобода, заключение: «Я не хочу ничего материнского. Даже своего тела» [Чижова, с. 112]. Больное тело чувствуется обузой и потому отвергается: «Я хочу на свободу $<\ldots>$ Я не хочу смотреть на себя в зеркало, ни с ребенком, ни без. Никогда» [Там же, с. 113]. Апельсины, которые приносят «обеспокоенные матери» [Там же, с. 112] в обмен на заботу об их детях, становятся приметой болезненного, ненормального состояния, наполненного «желтой, материнской кровью» [Там же, с. 113]. В конце романа Ф. принимает материнскую заботу главной героини только из-за обреченности и болезни, она уже несвободна и не может решать свою судьбу самостоятельно. Возраст и тайная влюбленность ученицы в учительницу не делают отношения мать-дочь полноценными или традиционными. Таким образом, мы видим отторжение данной модели поведения, которая не способна выстроить истинную идентичность или подлинность женщины.

Отвергнув материнско-дочернюю модель как непродуктивную, Ф. продолжает поиск собственного «я» через другие категории, которые мы также можем почерпнуть в работах известного теоретика феминизма Люси Иригарэ.
Известно, что существует пять типов субъективации: женский, мужской, гомосексуальный, гетеросексуальный и транссексуальный. Все они становятся предметом изучения гендерных исследований, которые выделяют критерий иного как базовый для всей методологии [Жеребкина И. А. с. 51]. Так и теория Люси Иригарэ базируется на методологии женского как иного. Эта концепция построена на доказательстве подобной женской репрезентации в культуре. Целью Иригарэ является одновременно и деконструкция традиционного фаллоцентристского представления о женщине как о «другом» мужчине, так и выявление способов, с помощью которых женская специфичность может быть выражена в дискурсе в присущих только ей, автономных терминах [Там же, с. 56].

Женщина, по словам Иригарэ, не «одно», но «два в одном» - то есть множественность, децентрированность, диффузность, вместо отношений идентичности она воплощает отношения длительности, механизм действия которых не подчиняется логическому закону непротиворечивости [Там же, с. 51].

Обретение женской идентичности возможно в романе во вновь созданном квазибытии. Самоощущение себя, высвобождение из оков мужского мира происходит у Ф. только через искусство, которое является «иллюзорным воссозданием, удваивающим реальное бытие художественнообразным квазибытием» [Каган, с. 197]. Ф. необходимо множиться, чтобы чувствовать себя полной. Ее мир целостен, неделим, закрыт для посторонних. Этот маленький мир строится в оппозиции к большому, с присущим первому «свойством, которым не может похвастаться большой мир. Это свойство иелостности» [Чижова, c. 29]. Так задается пространственная оппозиция между миром Ф. (можно додумать: феминным) и «большим миром» школы и шире - СССР.

Говоря о поисках феминности, Иригарэ постулирует и поиски языка как способа обретения феминности. Это язык, который «говорит до речи», - некий утопический язык, который существует «вне и помимо слов», значение которого фиксируется в артикуляционной речи [Жеребкина И. А., с. 555]. В романе выстраивается языковая оппозиция «русский - английский», где русский отвечает за мужское, советское, доминирующее, патриархальное. Отказ от языка, ставшего родным (но не являющимся таковым по сути), можно расценить как отказ от мужского, 
традиционного «большого мира» в поиске себя, своей сущности. Инаковость во владении языком Ф. заявляется с первого ее появления в школе: «Она говорила свободно и быстро <..> Почти не глядя на нас, она рассказывала какую-то свою историю» [Чижова, с. 41].

Эти две оппозиции - языковую и пространственную - можно сравнить с противопоставлением мужского и женского, где школа, страна, СССР воспринимаются как мужское, враждебное, довлеющее над миром театра Ф., но не способное стать частью его. «Большой мир» лишь наблюдает или пожинает плоды, как Крошка Цахес, но не проникает за границы этого мира, созданного женщиной. Так, Maman и Б.Г. выслуживаются перед районо и иностранными делегациями, показывая выступления школьного театра, но не могут стать причиной происходящих в нем событий. Личность Maman, прозвище которой вновь отсылает нас к мотиву материнского, не играет никакой роли, и является лишь декоративной вершиной власти, ничего по-настоящему не меняющей и лишь существующей в «большом мире» школы. Ее роль даже менее значительна, чем роль Б.Г. - так называют в школе завуча английского языка Бориса Григорьевича Каца (это мужчина «сорока пяти лет, еврей и дипломат, воплощенная деликатность» [Там же, с. 24]). Национальная принадлежность в силу исторических обстоятельств делает Б.Г. уязвимым для «большого мира», а значит, в какой-то степени «своим» для мира женского квазибытия. Поэтому Б.Г. отводится небольшая роль в судьбе театра. К нему идет главная героиня и Ирка, чтобы пожаловаться на Федькино предательство.

Ф. создает свой мир, чтобы почувствовать свободу от чуждого ей советского (мужского), доминирующего бытия. Еще одно свойство этого квазибытия: «эта изелостность никоим образом не означала однородность» [Там же, с. 29]. Стремление Ф. стать чем-то «большим, чем одно» не требует, как пишет Иригарэ, «ничего внешнего (ничего „другого“) для своего осуществления и удовлетворения и подразумевает децентрализацию фаллоса, а значит, открытие новых телесных - женских - пространств» [Жеребкина И. А., с. 68]. Удаление концепта «мать» подспудно убирает и фигуру «отца», которой в романе отводится малозначительная роль еще до появления театра Ф.: привезти колготки из Чехословакии, чтобы дать дочери возможность (упущенную) продвинуться в школьной иерархии. Пожалуй, самый примечательный эпизод, связанный с отцом, происходит в первый День Театра. Мелодекламация сонета Шекспира его дочерью не была оценена, в отличие от скоморош- ной пародии на «Гамлета» Федьки и Мишки. Это предпочтение моментально выкидывает его из канвы повествования, делая частью «большого мира».

Вообще, хохот раздражает Ф., вызывает скуку. Она, словно кость, бросает толпе со сцены подобные «грустной истории Йорика» [Чижова, c. 60], понимая низкие запросы и презирая зрителя за них: «Она смотрит в сторону, как будто ее самой нет в этом хохочущем зале, в зале, который она сама вздернула на дыбу - хохотать» [Там же, с. 81]. Хохот представляется чем-то низменным, смердящим, плебейским: «их оголтелом хохоте», "...У кухонных распаренные лиия, хохотали до слез» [Там же], «беснующийся в хохоте зал» [Там же, с. 84], «учителя хохотали как бешеные» [Там же, 87], «медленно вскипает хохот» [Там же, с. 97], «они выли и хохотали как умалишенные» [Там же, с. 167].

Именно с хохота, по словам рассказчицы, начинается падение театра Ф. Городской конкурс самодеятельных театров принес хохот, что «закипал за нашими спинами» [Там же, с. 167], клубился и пенился, в нем терялись реплики Ромео и Джульетты, превращаясь в «опозоренные звуки» [Там же]: «...Их хохот катился внятныли судорожныли волнами, то нарастая, то затихая, как тяжельй приступ» [Там же]. Непонятые, опустошенные с «зудящим стылом» [Там же, с. 168] в глазах, оскверненные пустым, бессердечным залом, способным лишь на хохот, они были изгнаны из «nустой mbмbl» [Там же] зрительного зала - метафоры женского лона, так началось их падение с вершины.

Прежде чем подойти к теме разрушения квазибытия Ф., необходимо оговорить восприятие самой Ф. ее подопечных: «дети - оборотни» с прекрасными лицами с беспросветной обратной стороной [Там же, с. 175]. Перед нами культурный концепт монструозного, существующего на грани антропоморфного и неантропоморфного и на стыке двух миров [Эстетика: слов, с. 28]. Дети воспринимаются как существа не цельные, несовершенные. Они тот дисгармоничный вид монструозности, «в основе которого лежит противопоставление / несовпадение внешнего и внутреннего: видимая физическая красота скрывает не воспринимаемое глазом духовное безобразие, основанное на бездушности, холодности, нравственной аномальности, т. е. не-антропоморфности, „снимающей“ законы человеческой морали» [Демидова, с. 55]. Монструозный дискурс в романе играет амбивалентную роль: с одной стороны, он впускает детей в пересозданный мир, дает им возможность стать частью целого (ведь они тоже «иные», как и женщина), с другой сто- 
роны - именно дети и становятся разрушителями этой целостности.

Первопричиной распада становится мужчина - Федька. Крошки Цахес вырываются из-под контроля, решив поставить американскую «настоящую современную пьесу» [Чижова, с. 171]. Федька не понимает своей роли в мире Ф., он, как мужчина, наделенный самой Ф. монструозными чертами оборотня, стремится занять место женщины, стать ей, применив названные Иригарэ мужские императивы: «насильственно войти», «проникнуть», «самому овладеть тайной утробы, где был зачат, секретом рождения», «истока» [Жеребкина С. В., с. 128]. То, как Федька говорит о своей пьесе, выдает его отношение к театру Ф. и ее репертуару: «настоящая современная пьеса, наши проблемы, естественные» [Чижова, с. 171]. Он вскрывает оппозицию «мужское - женское», отделяя свое «я» от феминного «я» Ф.; говоря «естественные», он признает Ф. - неестественной, безумной, непонятной его мужскому миру. Он презентует позицию традиционного, патриархального мира, оценивая феминное с негативной точки зрения.

Осознание своей неестественности проговаривает и рассказчица. Детское унижение через проживание своей телесности становится первым шагом в понимании своей инаковости: «mbl - урод, не как все дети, эта только ссыт, полюбуйтесь, снимай с себя все обоссанное и убирайся вон, теперь стирай за ней, нарожают уродов» [Там же, с. 21]. «Большой мир» проявляет свое покровительство, он смиряется с существованием «урода» из-за ощущения своего великодушия и милосердия: «никто не придет к тебе, кроме нас, потому что ты - урод, но мы милосерднь, и так будет всегда» [Там же, с.22].

Чувство унижения возвращается после предательства Федьки, когда дети признают в главной героине предателя, отщепенца, называя «её холуйка, рабыня, прислужница, прихвостень, подпевала» [Там же, с. 171]. Они снова выстраивают оппозицию между «большим миром» и главной героиней, тем самым выдавливая себя из квазибытия навсегда, разрушая его целостность, неделимость. В предпоследней главе героиня окончательно отвергает любовь Кости: «Такого, как он, я не полюблю никогда. Против всего мира. Я - не леди Анна. Я - не Настасья Филипповна. $Я$-урод. Мне не впервой» [Там же, c. 195].

Таким образом, в романе происходит деконструкция материнско-дочернего сюжета как враждебного и разрушающего. Он не способен стать базой для поиска феминной идентичности, чего нельзя сказать о создании собственного мира (квазибытия), живущего по своим законам и принципам, принимающего лишь особых - в чем-то уязвимых, в чем-то иных - людей. Сюда закрыт путь филистерам, тем, кто живет по законам большого (мускулинного) мира, который стремится забрать все лавры, стать тем самым Крошкой Цахесом, присваивающим таланты и славу других.

\section{Список литературы}

Демидова О. Р. Сон разума рождает чудовищ: концепт монструозного в культуре // Вестник Северного (Арктического) Федерального университета. Серия: Гуманитарные и социальные науки. 2017. № 1. С. 52-59.

Жеребкина И. А. Феминистская теория 90-х годов: проблематизация женской субъективности // Введение в гендерные исследования. Ч. І: Учебное пособие, под ред. И. А. Жеребкиной. СПб.: Алетейя, 2001. С. 49-80.

Жеребкина С. В. Введение в гендерные исследования. Ч. II: Хрестоматия. СПб.: Алетейя, 2001. 991 с.

Каган М. С. Философская теория ценностей. СПб: ТОО ТК «Петрополис», 1997. С. 197

Чижова Е.C. Крошки Цахес: роман. М.: АСТ: Астрель, 2011.220 с.

Эстетика: слов. Безобразное М., 1989. С. 28

\section{References}

Chizhova, E. S (2011). Kroshki Tsakhes [Little Zacheses]. 220 p. Moscow, AST, Astrel. (In Russian)

Demidova, O. R. (2017). Son razuma rozhdaet chudovishch: kontsept monstruoznogo v kul'ture [The Dream of Reason Gives Birth to Monsters: The Concept of Monstrous in Culture]. Vestnik Severnogo (Arkticheskogo) Federal'nogo universiteta. No.1, pp. 5259. Arkhangelsk. (In Russian)

Estetika: slov. Bezobraznoe (1989) [Aesthetics: Word Ugly]. 28 p. Moscow, Politizdat. (In Russian)

Kagan, M. S.(1997). Filosofskaia teoriia tsennostei [Philosophical Theory of Values]. 197 p. St. Petersburg, TOO TK Petropolis. (In Russian)

Zherebkina, I. A. (2001). Feministskaia teoriia 90-kh godov: problematizatsiia zhenskoi sub"ektivnosti .Vvedenie $v$ gendernye issledovaniia. Ch. I. [Feminist Theory of the 1990s: Problematization of Female Subjectivity. Introduction to Gender Studies. Part I ]. Pp. 49-80. St. Petersburg, Ale-teiia. (In Russian)

Zherebkina, S. V. (2001). Vvedenie $v$ gendernye issledovaniia. Ch. II: Khrestomatiia [Introduction to Gender Studies. Part II: Reader]. 991 p. St. Petersburg, Ale-teiia. (In Russian) 


\section{Бреева Татьяна Николаевна,} доктор филологических наук, профессор,

Казанский федеральный университет, 420008, Россия, Казань,

Кремлевская, 18.

Tatyana.Breeva@ksu.ru

\section{Панибратова Юлия Федоровна,}

магистрант,

Казанский федеральный университет, 420008, Россия, Казань, Кремлевская, 18.

jfpanibratova@gmail.com
Breeva Tatyana Nikolaevna,

Doctor of Philology,

Professor,

Kazan Federal University,

18 Kremlyovskaya Str.,

Kazan, 420008, Russian Federation.

Tatyana.Breeva@ksu.ru

\section{Panibratova Youliya Fedorovna,}

Master's student,

Kazan Federal University,

18 Kremlyovskaya Str.,

Kazan, 420008, Russian Federation.

jfpanibratova@gmail.com 